fascination to the geographer, geologist, and botanist in particular, and may lead to the despatch of an Expedition on a larger scale and with a wider scientific scope.

It may be of interest here briefly to recall the attempts which have been made from time to time to cross the Greenland continent.

As is well known, Greenland has never been crossed by human being, although there is a tradition, confirmed by Holm and Garde, that a young girl from Pikiudelek, on the east coast, driven from home by cruelty, wandered on foot across the ice to the west coast. However, in modern times many attempts have been made, as, for instance, by Dalager (a Dane), Dr. John Rae. Messrs. Whymper and Brown, Messrs. Jensen, Kornerup, and Groth, and Nordenskiöld in 1870 and 1883 . All of these attempts were failures, with the exception of that of Nordenskiöld in 1883 referred to, when he succeeded, in lat. $681^{\circ} \mathrm{N}$, in reaching 75 miles inland, and his two Lapps 140 miles further, or 215 miles, i.e. a little more than half the width of the country. Finally, we have the scantily-known wandering, in June of last year, of Mr. Peary, an Amerian engineer, and Herr Maigaard, a Dane, who claim to have reached about Ioo miles inland on the ice from Jakobshavn, and reached an elevation of about 7000 feet above the sea; but the weather was unfavourable. It is worthy of note that this elevation is far higher than that recorded by Nordenskiöld a little further south, viz. about 6000 feet.

It is impossible to close this résumé of Dr. Nansen's plans without referring to the much-disputed theory of there being, if not a fertile interior somewhere in Greenland, at all events land free from ice and snow, as advocated by Nordenskiöld, but which he failed to find. We have it however now, on the authority of Dr. Nansen, that in spite of this failure the famous Swedish explorer is still of opinion that such conditions may exist somewhere to the north or south of the track followed by himself. Dr. Nansen also supports this theory, which is, leaving the "Föhn" wind theory out of the question, based, firstly, on the circumstance that the reindeer herds on the west coast disappear from the coast in the summer, when it is surmised that they proceed to this interior "oasis," as it has been termed; and, secondly, on the discovery by Nordenskiöld of reindeer horn far in on the ice; thirdly, the theory is claimed to be supported by the fact of Nordenskiöld's two Lapps having in the middle of Greenland seen two ravens coming from the north to "have a look at them," and return in the same direction. Hence, it is maintained, some ice-free land must exist further north. But as to the wanderings of the reindeer, such take place every summer in Norway, when the animals repair to the glaciers in order to escape from their dread tormentors the gadfly and the heat. It is, however, curious that the Greenlanders themselves, as well as the Eskimo, according to Captain Holm, firmly believe in an ice-free and populated interior, the inhabitants of which are of encrmous stature, fierce, and dangerous magicians, and it is this latter belief which is the cause of the natives refusing to act as guides or participate in explorations of the interior. The east coast natives by the way maintain, too, that Scoresby Sound in the extreme north (Holm, "East Coast Expedition, I $883^{-85}$ ") is a fjord separating Greenland from the rest of the Arctic regions; that once a Greenlander sailed through it from west to east, and that near its southern shores resides a warlike tribe of Greenlanders.

It was Dr. Nansen's intention to have attempted to land in the neighbourhood of Scoresby Sound, where no European has ever set foot, but it was impossible to get further north than Cape Dan on account of ice. It should be mentioned that the present expedition is in a great degree due to the munificence of Herr Augustus Gamél, of Copenhagen, who despatched Lieutenant Hovgaard's Arctic Expedition of $\mathrm{I} 88 \mathrm{o}$, and has received valuable assistance from such Greenland explorers as Nordenskiöld, Rink, Holm, Ryder, and Marigaard, as well as the Royal Geographical Society.

If all goes well, it may return to Europe before the last vessel leaves Greenland at the end of September.

If successful, it cannot fail to throw some further light upon the interesting scientific problems of that mystic northern continent, and incite other explorers to follow in Dr. Nansen and his colleagues' footsteps.

\section{THE CENTENARY OF THE CALCUTTA BOTANIC GARDEN.}

THE Report of Dr. George King, the Superintendent of the Botanic Garden of Calcutta, for the past year gives a brief history of the work of that institution during the century of its existence, which has just been completed. The suggestion for its foundation was made to the Government in Calcutta in 1786 by Colonel Robert Kyd, then Superintendent of the East India Company's dockyard at Kidderpore. The adoption of the proposal was urged upon the Board in London by the GovernorGeneral, and upon their sanctioning it a large piece of land at Shalimar was chosen as the site, and Colonel Kyd was elected the first Superintendent. He held the post till his death in 1793. At the outset it was understood that the Garden was to be made a source of information for the Company's servants, and a place in which experiments could be made on those exotics which were of economic value. It was also intended to be a horticultural and agricultural garden, which would assist in introducing indigenous Indian products to new markets. The earliest efforts of Colonel Kyd were directed to the introduction of trees yielding nutmeg, cloves, and cinnamon, and to attempt to cultivate them. This, however, was a failure, the climate being shown to be quite unsuitable to them. The equatorial fruits, such as mangosteen and bread-fruit were tried with a similar result, and also the temperate fruits of Europe, and thus at an early stage it was demonstrated that any such effort was quite useless. Colonel Kyd introduced tea cultivation, and in this he was highly successful, and it was owing to his efforts that the tea-industry has become one of the most important in India. On the death of Colonel Kyd, Dr. William Roxburgh, the Company's Botanist in Madras, was appointed to the post, and continued in it till I8I4. He was an ardent botanist, and was the first who attempted to draw up a systematic account of the plants of India. His Flora Indica contained descriptions of all the indigenous plants he had met, and also of the exotics in cultivation at Calcutta. This book was not published till I 832, and it was, till Sir Joseph Hooker commenced his work on the "Flora of British India" in 1872 , the only book from which a good knowledge of Indian plants could be acquired. Besides his "Flora Indica," Roxburgh published "Plantæ Coromandalianæ," descriptions of three hundred of the most representative plants on the Coromandel Coast. Dr. Roxburgh, who left India on account of failing health, was succeeded by Dr. BuchananHamilton, who collected a mass of information about the fauna and flora of India, a portion of which he published in his own name, but the greater part was issued in Montgomery Martin's "History, Topography, and Statistics of Eastern India." In 1817 , Dr. Wallich became Superintendent. Wallich was a most energetic man, and during his term of office he made collections in Kumaon, Nepal, Tenasserim, Singapore, Penang, and other places. His collections of dried plants were taken by him to London, and after their classification they were distributed to the chief botanical institutions in Europe. Dr. Wallich published three fine volumes, "Plantx Asiaticæ Rariores," illustrated with excellent figures. On Dr. Wallich's retirement in 1846 , Dr. Hugh Falconer, who 
is well known on account of his researches on the Sivalik fossil Mammalia, succeeded to the post. Dr. Thomas Thomson, the co-worker of Sir Joseph Hooker in the collection and distribution of an extensive East Indian Herbarium, was the next Superintendent. His successor, Dr. Thomas Anderson, died in 1870 from disease contracted when labouring to introduce the quinine-yielding Cinchonas into the Himalayas. This latter work-that is, the cultivation of the Cinchonas of the Andes-has been a great success. The (arden authorities, in connection with the Agri-Horticultural Society of India, made great and successful efforts to improve the quality of Indian cotton, and to push its sale and that of jute in the European markets. The united bodies also imported better kinds of sugar-cane from the West Indies, and thus improved the quality and the amount of the sugar-crop in India. The various Superintendents made from time to time experiments in the cultivation of plants and products of economic value, as, for instance, tapioca, india-rubber, sarsaparilla, aloes, cocoa, and many others. Many of the various kinds of exotics now grown in India have been introduced through the instrumentality of the Garden, and the aithorities have shown to the in habitants of India the advantages of better systems of cultivation than they previously pursued.

In the year I 864 the Garden was devastated by a terrible cyclone, and the few plants that escaped the general ruin were very much thinned by another cyclone which a few years after burst over Calcutta. In fact, at the present moment there are in the Garden only a few trees, including the great banyan, which were there in 1867 . When the shade of the trees was thus removed, the weed Imperate cylindrica spread rapidly over the whole Garden, and when Dr. King was appointed to be Superintendent of the Garden, in $187 \mathrm{I}$, he found it in rather a sorry plight. By the assistance that the local authorities gave him he was enabled to plant it afresh, to lay it out for landscape effect, to form ornamental ponds, and to build the Herbarium and conservatories. The most noticeable feature from a botanical stand-point is, of course, the Herbarium. On Dr. Wallich dispersing in 1828 the splendid collection of dried plant ${ }^{2}$, the foundations of another were laid. Almost every botanical student in India has contributed to the present collection, and also many specimens have been sent from Europe. Of course it is above all an Indian Herbarium, but there are also good collections of plants from Asia Minor, Persia, Japan, and South-Eastern Asia. In fact, in all but African and American plants it is a very representative collection. For the last fifty years there has been a constant exchange of specimens with Kew Gardens, and to Sir William Hooker, and Sir Joseph Hooker, and Mr. Thiselton Dyer, the Herbarium owes some of its choicest specimens. Exchanges have also been systematically made with the British Museum Herbarium, the Jardin des PJantes, Paris, the Imperial Gardens at Berlin and St. Petersburg, and with the institutions at Ceylon, Java, and Saharanpore, and many of the best-known botanists have been among the most active contributors.

During the past year the collection of dried plants has been largely increased, the most noteworthy additions bing those collected by Dr. Aitchison with the Afghan Boundary Commission, and those by Dr. Giles during the Gilgit expedition, the latter having been sent from Kew. From Kew were also received many specimens of Singapore and Penang plants. Many plants from Central Asia were sent by the Iirector of the Imperial Garden at St. Petersburg, and a Natal collection was sent from Durban. Four hundred named species from Mexico, a large box of dried plants from New Guinea, a quantity of plants from Sikkim, trees from the Khasia Hills, specimens from the North-Western Himalayas, and from Southern India, were among the many collections presented to the Garden in the past year. The
Government Botanist of Perak, Father Scortechini, who had been sent by Sir H. Low, came to the Garden in November to study, so that he might arrange his collections, but he died shortly after his arrival. During the year 8064 plants were received and 46, Iog given out; 903 packets of seeds were received, and 25.34 distributed. Dr. King concludes his Report by saying that the acclimatized English potatoes have everywhere turned out badly the past season.

\section{THE BRITISH ASSOCIATION.}

\section{SECTION G.}

MECHATICAL SCIENCE.

Opening Adpress by William Henry Preece, F.R.S., M.Inst.C.E., \&C;, Presidext of the Section.

"CANST thou send lightnings, that they may go, and say unto thee, Here we are?" were pregnant words addressed to Tob unknown centuries ago. They express the first recorded idea in history of the potentiality of electricity to minister to the wants of mankind. From Job to Franklin is a long swing in the pendulum of time. It was not until that American philosopher brought down atmospheric electricity by his kite-string in 1747 , and showed that we could lead it where we willed, that we were able to answer the quistion addresserl to the ancient patriarch. Nearly another century elapsed before this mysterious power of Nature was fairly conquered. It has been during this generation, and during the life of the British Association, that electricity has been usefully employed; and it is because I have taken a subordinate position in inaugurating nearly all of its practical applications, that I venture to make the developments of them the text of my arddress to this Section.

People are singularly callous in matters affecting their own personal safety: they will not believe in mysteries, and they ridicule or condemn that which they do not understand. The Church itself set its face against Franklin's "impious" theories, and he was laughed to scorn by Europe's scientific sons: and even now, though Commissions composed of the ablest men of the land have sat and reported on Franklin's work in Lingland, France, and nearly every civilized nation, the public generally remains not only ignorant of the use of lightning-conductors, but absolutely indifferent to their erection, and, if erected, certainly careless of their proper maintenance. I found in a church not very far from here the conducter leaded into a tombstone, and in a neighbouring cathedral the conductor only a few inches in the ground, so that I cotuld draw it out with my hand. Although I called the attention of the proper authorities to the absolute danger of the state of affairs, they remained in the same condition for years.

Wren's beautiful steeple in Fleet Street, St. Bride's, was wellnigh destroyed by lightning in 1764 . A lightning-rod was fixed, hut so imperfectly that it was again struck. In July last (1887) it was damaged because the conductor had been neglected, and had lost its efficiency.

As long as points remain points, as long as conductors remain conductors, as long as the rods make proper connection with the earth, lightning protectors will protect : but if points are allowed to be fused, or to corrode away; as long as bad joints or faulty connections are allowed to remain; as long as bad earths, or no earths exist, so long will protectors cease to protect, and they will become absolute sources of danger. Lightning-conductors, if properly erected, duly maintained, and periodically inspected, are an absolute source of safety; but if erected by the village blacksmith, maintained by the economical churchwarden, and never insp cted at all, a loud report will some day be heard, and the beautiful steeple will convert the churchyard into a new geological formation.

We have not yet acquired that mental confidence in the accuracy of the laws that guide our procedure in protecting buildings from the effects of atmospheric electrical discharges which characterizes most of the practical applications of elec. tricity. Some of our cherished principles have only very recently received a rough shaking from the lips of Prof. Oliver Lodge, F.R.S., who, however, has supported his brilliant expe:iments by rather fanciful speculation, and whose revolutionary conclusions are scarcely the logical deduction from his 